\title{
Protective effects of Quercus salicina on alloxan-induced oxidative stress in HIT-T15 pancreatic $\beta$ cells
}

\author{
JIA-LE SONG ${ }^{1 *}, \mathrm{XIN}_{\mathrm{ZHAO}}{ }^{* *}$ and QIANG WANG ${ }^{2}$ \\ ${ }^{1}$ Department of Food Science and Nutrition, Pusan National University, Busan 609-735, Republic of Korea; \\ ${ }^{2}$ Department of Biological and Chemical Engineering, Chongqing University of Education, Chongqing 400067, P.R. China
}

Received November 28, 2012; Accepted January 2, 2013

DOI: $10.3892 /$ etm.2013.885

\begin{abstract}
The present study was designed to investigate the protective effect of hot water extracts from Quercus salicina leaves (QSWE) on alloxan-induced oxidative stress in HIT-T15 Syrian hamster pancreatic insulinoma cells. The HIT-T15 cells were treated with alloxan $(1 \mathrm{mM})$ for $1 \mathrm{~h}$ and then co-incubated with the QSWE for $24 \mathrm{~h}$. Alloxan significantly decreased the viability of the HIT-T15 cells $(\mathrm{P}<0.05)$. QSWE did not exhibit significantly cytotoxic effects and increased the viability of the HIT-T15 cells in a concentration-dependent manner. To further investigate the protective effects of QSWE on alloxan-induced oxidative stress in HIT-T15 cells, the cellular levels of reactive oxygen species (ROS), lipid peroxidation and endogenous antioxidant enzymes, including catalase (CAT), superoxide dismutase (SOD) and glutathione peroxidase (GSH-px), were analyzed. QSWE decreased the intracellular levels of ROS and lipid peroxidation and increased the activity of antioxidant enzymes. These results suggest that QSWE exerted cytoprotective activity against alloxan-induced oxidative stress in HIT-T15 cells through the inhibition of lipid peroxidation, reduction of ROS levels and stimulation of antioxidant enzyme activity. In addition, QSWE also increased the insulin secretion activity of the alloxan-treated HIT-T15 cells.
\end{abstract}

\section{Introduction}

Diabetes mellitus has progressively become a serious public health problem worldwide. Reactive oxygen species (ROS)-induced pancreatic $\beta$ cell death has an important role in the pathogenesis of diabetes and also affects insulin secretion. The ROS that are particularly responsible for oxidative stress

Correspondence to: Dr Xin Zhao, Department of Biological and Chemical Engineering, Chongqing University of Education, 9 Xuefu Main Street, Nan'an, Chongqing 400067, P.R. China

E-mail: zhaoxin@pnu.edu

\section{*Contributed equally}

Key words: Quercus salicina, pancreatic $\beta$ cells, cell viability, reactive oxygen species, insulin secretion include superoxide ions $\left(\mathrm{O}_{2}^{-}\right)$, hydroxyl radicals $\left({ }^{\circ} \mathrm{OH}\right)$, singlet oxygen $\left({ }^{1} \mathrm{O}_{2}\right)$, hydrogen peroxide $\left(\mathrm{H}_{2} \mathrm{O}_{2}\right)$, nitric oxide $(\mathrm{NO})$ and peroxynitrite $\left(\mathrm{ONOO}^{-}\right)$. Oxidative stress induces the dysfunction of pancreatic $\beta$ cells, decreases insulin secretion (1) and leads to diabetic complications, including retinopathy, nephropathy, neuropathy and vascular damage (2,3). Generally, mammalian cells contain various antioxidative compounds, including low molecular mass antioxidants such as glutathione (GSH), uric acid, vitamin C and vitamin E, as well as various endogenous antioxidant enzymes against oxidative stress. Superoxide dismutase (SOD), catalase (CAT) and glutathione peroxidase (GSH-px) are three important endogenous antioxidant enzymes with roles against ROS-induced oxidative stress in living organs. Among these antioxidant enzymes, SOD catalyses the dismutation of the superoxide anion $\left(\mathrm{O}_{2}^{-}\right)$into hydrogen peroxide $\left(\mathrm{H}_{2} \mathrm{O}_{2}\right)$ which is transformed into $\mathrm{H}_{2} \mathrm{O}$ and $\mathrm{O}_{2}$ by CAT. GSH-px is key in removing lipid hydroperoxides and reducing free hydrogen peroxide to water.

Certain drugs which are used in clinical diabetes mellitus treatment are also associated with undesirable side-effects, such as gastrointestinal disturbances, edema, myocardial infarction and risk of cardiovascular disease (4,5). For these reasons, the development of more effective and safer drugs for treating diabetes has become essential. Currently, $>400$ traditional plant treatments for diabetes have been recorded (6). It is possible that anti-diabetic components from those natural plants may be ancillary medicines for diabetes.

Quercus salicina is an evergreen plant which grows in southern parts of the Korean Peninsula and Japan. It has exhibited anti-inflammatory, antiedemic, diuretic and litholytic activities and has been used to treat diarrhea, dysentery, dermatitis and hemorrhagia in Korean folk medicine (7-9).

The current study was designed to investigate the potential cytoprotective effects of QSWE on alloxan-induced oxidative stress and also to elucidate the mechanisms underlying its protective effects in HIT-T15 cells.

\section{Materials and methods}

Plant extract preparation. Fresh Quercus salicina leaves were purchased from a local market in Chongqing, China in August 2012. Quercus salicina hot water extract (QSWE) was prepared by boiling $100 \mathrm{~g}$ freeze-dried Quercus salicina leaves in 11 distilled water for $2 \mathrm{~h}$, followed by ultracentrifuging at 
$30,000 \mathrm{x} \mathrm{g}$ for $30 \mathrm{~min}$, filtering with a $0.4-\mu \mathrm{m}$ filter, concentrating by heat evaporation and freeze-drying. The QSWE was redissolved in dimethyl sulfoxide (DMSO) at a concentration of $50 \mathrm{mg} / \mathrm{ml}$ and stored at $4^{\circ} \mathrm{C}$ until further study.

Cell culture. HIT-T15 Syrian hamster insulin-secreting cells were obtained from the American Type Culture Collection (ATCC, Rockville, MD, USA). The cells were maintained in RPMI-1640 medium supplemented with $10 \%$ (v/v) fetal bovine serum (FBS) and $1 \%$ penicillin-streptomycin in a humidified $\mathrm{CO}_{2}$ incubator (Model 3154; Forma Scientific Inc., Marietta, $\mathrm{OH}, \mathrm{USA}$ ) with $5 \% \mathrm{CO}_{2}$ at $37^{\circ} \mathrm{C}$.

Cell viability assay. Cell viability was assessed using 3-(4,5-dimethylthiazol-2-yl)-2,5-diphenyltetrazolium bromide (MTT) assays. Cells were seeded on 96-well plates at a density of $5 \times 10^{3}$ cells/well. After a $24 \mathrm{~h}$ incubation, the cells were treated with alloxan $(1 \mathrm{mM})$ for $1 \mathrm{~h}$, then incubated with QSWE $(2.5-50 \mu \mathrm{g} / \mathrm{ml})$ for $24 \mathrm{~h}$. Following incubation, $100 \mu \mathrm{l}$ MTT reagent $(0.5 \mathrm{mg} / \mathrm{ml})$ was added to each well and the cells were incubated in a humidified incubator at $37^{\circ} \mathrm{C}$ to allow the MTT to be metabolized. After $4 \mathrm{~h}$, the medium was removed and the cells were resuspended in formazan with $100 \mu$ 1 DMSO. The absorbance of the samples was measured at $540 \mathrm{~nm}$ using a microplate reader (model 680; Bio-Rad, Hercules, CA, USA).

Analysis of intracellular ROS. Intracellular ROS levels were measured using the fluorescent probe dihydrodichlorofluorescein diacetate $\left(\mathrm{H}_{2} \mathrm{DCF}-\mathrm{DA}\right)$. Following treatment, the HIT-T15 cells were washed with calcium- and magnesium-free phosphate-buffered saline (PBS) and incubated in $\mathrm{H}_{2}$ DCF-DA $(20 \mu \mathrm{M})$ containing serum- and phenol-red-free DMEM for $30 \mathrm{~min}$. After incubation, the medium was removed and the cells were washed twice with PBS. Fluorescence was measured using a FLUOstar OPTIMA fluorescence plate reader (BMG Labtec, Ortenberg, Germany; excitation was read at $485 \mathrm{~nm}$ and emission at $535 \mathrm{~nm}$ ). Relative ROS production (percentage of the control) was expressed as the ratio of the fluorescence of the treated samples to the response in the appropriate controls: (Fluorescence treatment / fluorescence control) x 100.

Lipid peroxidation levels. Lipid peroxidation was evaluated by thiobarbituric acid (TBA)-reactive substance (TBARS) assays (10). In brief, the treated cells were washed with cooled PBS, scraped into trichloroacetic acid (TCA; $2.8 \%$, w/v) and sonicated. Total protein was determined with a bicinchoninic acid (BCA) assay. The suspension was mixed with $1 \mathrm{ml}$ TBA $(0.67 \%, \mathrm{w} / \mathrm{v})$ and $1 \mathrm{ml} \mathrm{TCA}(25 \%, \mathrm{w} / \mathrm{v})$, heated $\left(30 \mathrm{~min}, 95^{\circ} \mathrm{C}\right)$ and centrifuged $\left(1,500 \mathrm{rpm}, 10 \mathrm{~min}, 4^{\circ} \mathrm{C}\right)$. TBA reacts with the oxidative degradation products of lipids to yield red complexes that absorb at $535 \mathrm{~nm}$. The amount of TBA-reactive substance was determined using a UV-2401PC spectrophotometer (Shimadzu, Kyoto, Japan).

Antioxidant enzyme activity. HIT-T15 cells grown in 10-cm cell culture dishes were first treated with alloxan $(1 \mathrm{mM})$ for $1 \mathrm{~h}$ and then incubated with QSWE $(2.5-50 \mu \mathrm{g} / \mathrm{ml})$ for $24 \mathrm{~h}$ for further analysis. The cells were washed with PBS, detached by scraping and centrifuged, and the resulting cell pellet was stored at $-80^{\circ} \mathrm{C}$. Cell pellets were thawed, resuspended in $300 \mu \mathrm{l}$ cold lysis buffer (PBS, 1mM EDTA), homogenized and centrifuged $\left(1,200 \mathrm{rpm}, 10 \mathrm{~min}, 4^{\circ} \mathrm{C}\right)$. The resulting supernatants were used for activity measurements. CAT activity (U/mg protein) was measured according to the method described by Nelson and Kiesow (11) in which the disappearance of the substrate $\mathrm{H}_{2} \mathrm{O}_{2}$ was measured spectophotometrically at $240 \mathrm{~nm}$. SOD activity (U/mg protein) was assayed using a modified autoxidation of pyrogallol method (12). One unit of SOD activity was defined as the amount of enzyme that inhibited the rate of autoxidation of pyrogallol by $50 \%$. GSH-px activity (U/mg protein) was assayed according to the method of Hafemen et al (13). Protein contents were determined using a Bio-Rad protein assay kit according to the manufacturer's instructions.

Insulin secretion assay. Insulin secretion was measured with an ELISA assay. The cells were seeded at $5 \times 10^{5}$ cells/well in 96-well plates. The cells were first treated with alloxan $(1 \mathrm{mM})$ for $1 \mathrm{~h}$ and then treated with QSWE $(2.5-50 \mu \mathrm{g} / \mathrm{ml})$ for $24 \mathrm{~h}$. To measure the amount of insulin secreted, aliquots of samples (10 $\mu \mathrm{l} /$ well) were collected from the experimental medium after the 24-h QSWE treatment and subjected to an insulin antiserum immunoassay according to the manufacturer's instructions (LINCO Research, St. Charles, MO, USA). The absorbance was read at 450 and $590 \mathrm{~nm}$ in a microplate reader (model 680).

Statistical analysis. Data were presented as the mean \pm SD. Differences between the mean values for individual groups were assessed by one-way ANOVA with Duncan's multiple range tests. $\mathrm{P}<0.05$ was considered to indicate a statistically significant difference. The SAS v9.1 statistical software package (SAS Institute Inc., Cary, NC, USA) was used for the analyses.

\section{Results}

Effects of QSWE on alloxan-induced oxidative damage in HIT-T15 cells. To investigate QSWE-induced cytotoxicity, HIT-T15 cells were first treated with various concentrations of QSWE (2.5-50 $\mu \mathrm{g} / \mathrm{ml})$ for $24 \mathrm{~h}$ and the cell viability was determined using MTT assays. QSWE did not exhibit any significant cytotoxicity and the cell viabilities were $>90 \%$ (Fig. 1). Based on these results, concentrations between 2.5 and $50 \mu \mathrm{g} / \mathrm{ml}$ were used for further studies. As shown in Fig. 2, alloxan (1 mM) significantly induced cell death in the HIT-T15 cells. However, following treatment with various concentrations of QSWE, the cell viability was increased in a concentration-dependent manner.

Effects of QSWE on alloxan-induced intracellular ROS levels in HIT-T15 cells. To investigate the protective effects of QSWE in alloxan-treated HIT-T15 cells, the intracellular ROS levels were evaluated using a fluorescent probe, $\mathrm{H}_{2}$ DCF-DA. As shown in Fig. 3, alloxan significantly increased the ROS levels compared with those in the normal cells. In the presence of alloxan, QSWE significantly reduced ROS generation in a concentration-dependent manner between 2.5 and $50 \mu \mathrm{g} / \mathrm{ml}$. The intracellular ROS levels were $188.6 \pm 13.7$, $174.9 \pm 8.9,169.5 \pm 8.8,160.5 \pm 6.8$ and $158.1 \pm 9.8 \%$ at $2.5,5,10$, 25 and $50 \mu \mathrm{g} / \mathrm{ml}$ QSWE, respectively. Treatment with the same 


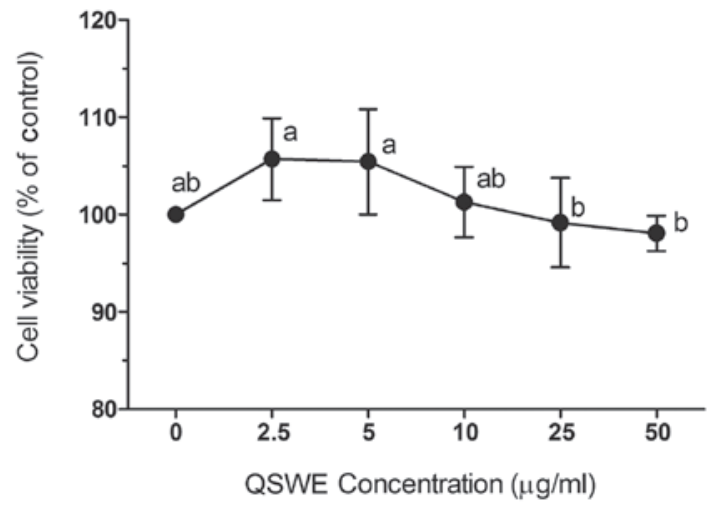

Figure 1. Effects of Quercus salicina leaf hot water extract (QSWE) on cell viability in HIT-T15 pancreatic cells. Data are representative of three independent experiments as mean $\pm \mathrm{SD}$. ${ }^{\mathrm{a}-\mathrm{b}}$ Mean values with different letters on the bars are significantly different from each other $(\mathrm{P}<0.05)$ according to Duncan's multiple range test.

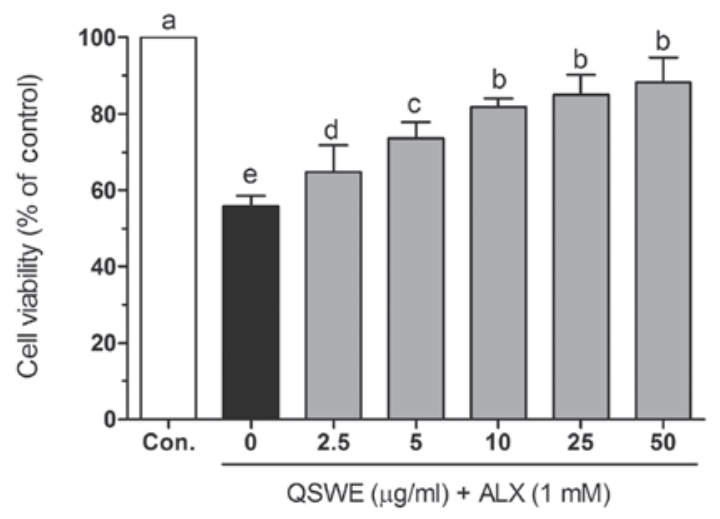

Figure 2. Effects of Quercus salicina leaf hot water extract (QSWE) on cell viability in $1 \mathrm{mM}$ alloxan (ALX)-treated HIT-T15 pancreatic cells. Data are representative of three independent experiments as mean \pm SD. ${ }^{\mathrm{a}-\mathrm{e}}$ Mean values with different letters on the bars are significantly different from each other $(\mathrm{P}<0.05)$ according to Duncan's multiple range test.

concentrations of QSWE alone did not significantly increase the intracellular ROS levels (data not shown). These results suggest that QSWE is a free radical scavenger.

Effects of QSWE on lipid peroxidation in alloxan-treated HIT-T15 cells. Free radicals and ROS-induced oxidative damage were markedly associated with the lipid peroxidation of cell membranes and increased the levels of malondialdehyde (MDA), which is a biomarker of cell membrane lipid peroxidation. As shown in Fig. 4, alloxan significantly increased the level of MDA (to $1.27 \pm 0.14 \mathrm{nmol} / \mathrm{mg}$ protein) compared with that in the normal cells $(0.35 \pm 0.03 \mathrm{nmol} / \mathrm{mg}$ protein). QSWE significantly reduced the MDA levels in a concentration-dependent manner between 2.5 and $50 \mu \mathrm{g} / \mathrm{ml}$. The MDA levels were 1.16 \pm 0.23 , $1.02 \pm 0.14,0.92 \pm 0.20,0.83 \pm 0.13$ and $0.78 \pm 0.11 \mathrm{nmol} / \mathrm{mg}$ protein at $2.5,5,10,25$ and $50 \mu \mathrm{g} / \mathrm{ml}$ QSWE, respectively.

Effects of QSWE on the activity of antioxidant enzymes in alloxan-treated HIT-T15 cells. Table I shows the intracellular antioxidant enzyme activities of QSWE in the alloxan-treated HIT-T15 cells. The activity of SOD was reduced by alloxan (to $7.25 \pm 0.68 \mathrm{U} / \mathrm{mg}$ protein) and this reduction was attenuated by

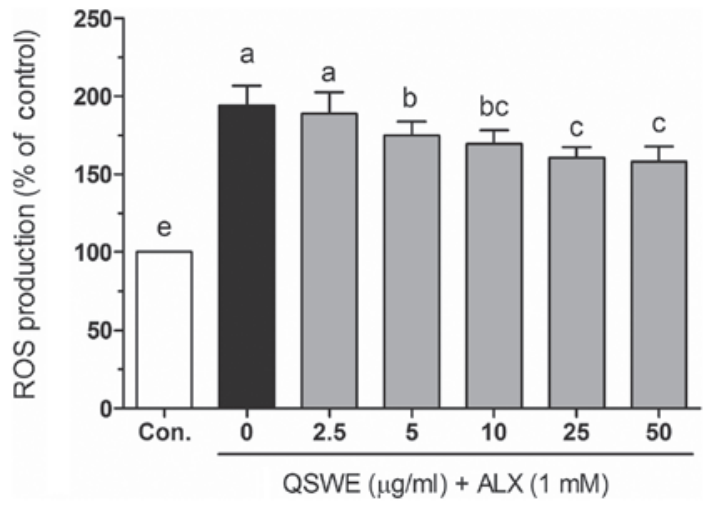

Figure 3. Effects of Quercus salicina leaf hot water extract (QSWE) on intracellular reactive oxygen species (ROS) levels in $1 \mathrm{mM}$ alloxan (ALX)-treated HIT-T15 pancreatic cells. Data are representative of three independent experiments as mean \pm SD. ${ }^{\mathrm{a}-\mathrm{e}}$ Mean values with different letters on the bars are significantly different from each other $(\mathrm{P}<0.05)$ according to Duncan's multiple range test.

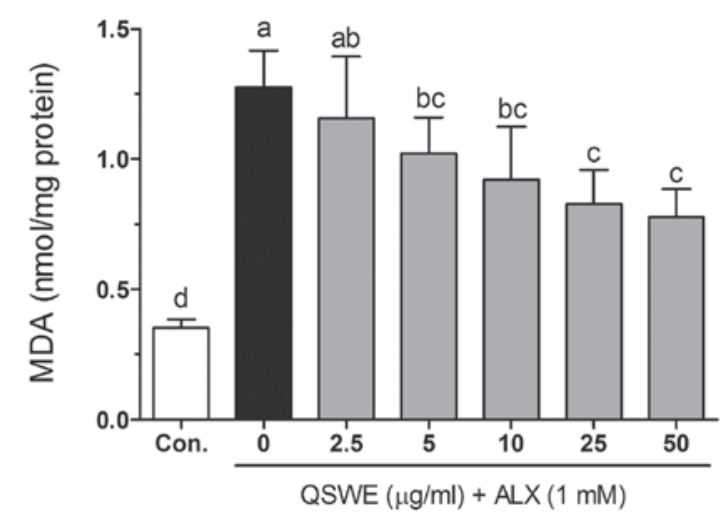

Figure 4. Effects of Quercus salicina leaf hot water extract (QSWE) on intracellular malonaldehyde (MDA) levels in $1 \mathrm{mM}$ alloxan (ALX)-treated HIT-T15 pancreatic cells. Data are representative of three independent experiments as mean $\pm \mathrm{SD}$. ${ }^{\mathrm{a}-\mathrm{d}}$ Mean values with different letters on the bars are significantly different from each other $(\mathrm{P}<0.05)$ according to Duncan's multiple range test.

various concentrations of QSWE; the SOD activity was 7.76 \pm 1.07 , $8.85 \pm 1.26,10.37 \pm 0.57,10.65 \pm 1.65$ and $11.60 \pm 1.18 \mathrm{U} / \mathrm{mg}$ protein at $2.5,5,10,25$ and $50 \mu \mathrm{g} / \mathrm{ml}$ QSWE, respectively. Following treatment with alloxan, the cellular CAT activity was reduced $(1.25 \pm 0.15 \mathrm{U} / \mathrm{mg}$ protein) compared with that in the normal cells $(2.11 \pm 0.24 \mathrm{U} / \mathrm{mg}$ protein). However, the reduction in CAT activity was significantly attenuated $(\mathrm{P}<0.05)$ by treatment with QSWE. In addition, QSWE also attenuated the alloxan-induced reduction in GSH-px activity in the HIT-T15 cells. The GSH-px activity of the alloxan-treated cells significantly increased following treatment with QSWE; the increased levels ranged from $3.29 \pm 0.15$ to $4.85 \pm 0.20 \mathrm{U} / \mathrm{mg}$ protein.

Effects of QSWE on insulin secretion in alloxan-treated HIT-T15 cells. As shown in Fig.5A, QSWEeffectively increased insulin secretion in normal HIT-T15 cells. However, alloxan significantly decreased the insulin level $(4,119.58 \pm 66.70 \mathrm{pg} / \mathrm{ml})$ compared with that in the normal cells $(10,411.66 \pm 159.14 \mathrm{pg} / \mathrm{ml})$. Following treatment with QSWE, the insulin levels in the alloxan-treated cells were 4,160.78 $\pm 67.36,4,490.35 \pm 72.70$, 
Table I. Effect of QSWE on the activity of CAT, SOD and GSH-px in HIT-T15 cells exposed to alloxan.

\begin{tabular}{lcccc}
\hline Group & QSWE concentration $(\mu \mathrm{g} / \mathrm{ml})$ & CAT (U/mg protein) & SOD (U/mg protein) & GSH-px (U/mg protein) \\
\hline Normal & - & $2.11 \pm 0.24^{\mathrm{a}}$ & $14.78 \pm 0.40^{\mathrm{a}}$ & $5.34 \pm 0.35^{\mathrm{a}}$ \\
ALX $(1 \mathrm{mM})+$ QSWE & 0.0 & $1.25 \pm 0.15^{\mathrm{c}}$ & $7.25 \pm 0.68^{\mathrm{d}}$ & $3.19 \pm 0.24^{\mathrm{e}}$ \\
& 2.5 & $1.68 \pm 0.24^{\mathrm{b}}$ & $7.76 \pm 1.07^{\mathrm{d}}$ & $3.29 \pm 0.15^{\mathrm{e}}$ \\
& 5.0 & $1.70 \pm 0.14^{\mathrm{b}}$ & $8.85 \pm 1.26^{\mathrm{cd}}$ & $3.74 \pm 0.32^{\mathrm{d}}$ \\
& 10.0 & $1.89 \pm 0.23^{\mathrm{ab}}$ & $10.37 \pm 0.57^{\mathrm{bc}}$ & $4.19 \pm 0.16^{\mathrm{c}}$ \\
& 25.0 & $1.95 \pm 0.07^{\mathrm{ab}}$ & $10.65 \pm 1.65^{\mathrm{b}}$ & $4.43 \pm 0.18^{\mathrm{c}}$ \\
& 50.0 & $2.04 \pm 0.14^{\mathrm{a}}$ & $11.60 \pm 1.18^{\mathrm{b}}$ & $4.85 \pm 0.20^{\mathrm{b}}$ \\
\hline
\end{tabular}

Data are representative of three independent experiments as mean $\pm \mathrm{SD} .{ }^{\mathrm{a}-\mathrm{e}}$ Mean values with different letters are significantly different from each other $(\mathrm{P}<0.05)$ according to Duncan's multiple range test. QSWE, Quercus salicina leaf hot water extract; CAT, catalase; SOD, superoxide dismutase; GSH-px, glutathione peroxidase; ALX, alloxan.

A
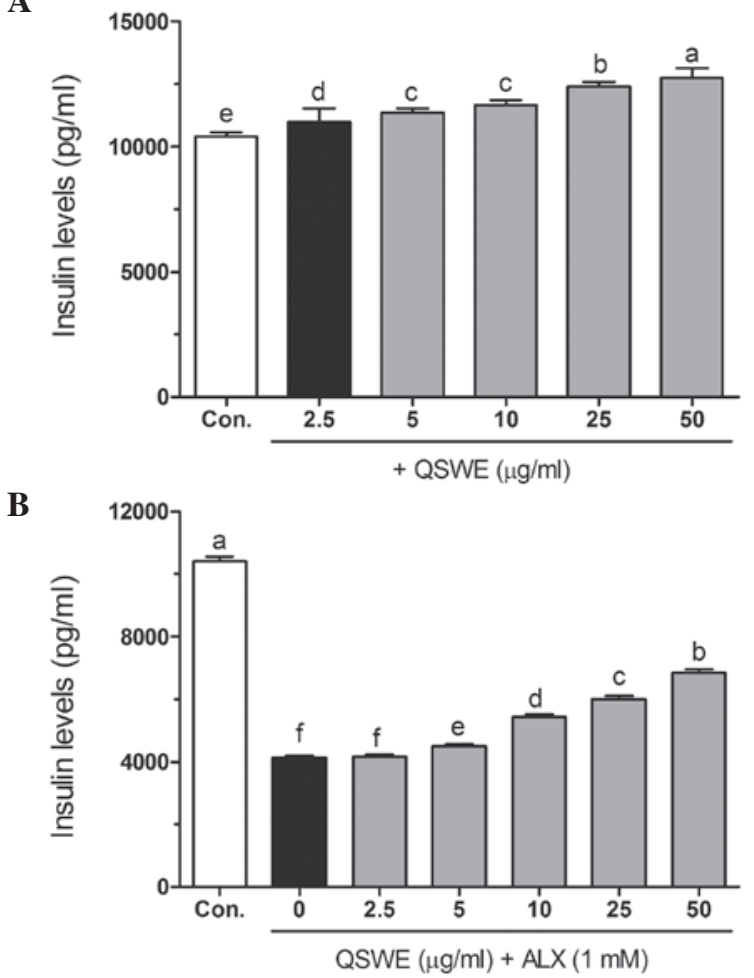

Figure 5. Effects of Quercus salicina leaf hot water extract (QSWE) on insulin levels in (A) normal and (B) $1 \mathrm{mM}$ alloxan (ALX)-treated HIT-T15 pancreatic cells. Data are representative of three independent experiments as mean \pm SD. ${ }^{\mathrm{a}-\mathrm{f}}$ Mean values with different letters on the bars are significantly different $(\mathrm{P}<0.05)$ according to Duncan's multiple range test.

$5,437.85 \pm 88.04,6,014.59 \pm 97.38$ and $6,846.02 \pm 116.42 \mathrm{pg} / \mathrm{ml}$ at at $2.5,5,10,25$ and $50 \mu \mathrm{g} / \mathrm{ml}$ QSWE, respectively (Fig. 5B). These results suggest that QSWE treatment is effective for increasing pancreatic $\beta$ cell survival and maintaining normal biological function in ROS-induced diabetes.

\section{Discussion}

ROS-induced oxidative damage in pancreatic $\beta$ cells is considered to have an important role in the pathological process of diabetes. Certain studies have reported that reducing ROS levels and treatment with antioxidants (such as NAC, vitamin C and vitamin $\mathrm{E}$ ) are able to improve $\beta$ cell structure and function in vitro $(14,15)$. However, whether QSWE protects pancreatic $\beta$ cells from alloxan-induced oxidative damage has not been investigated. The present study demonstrated that QSWE was able to protect HIT-T15 cells from ROS-induced cell damage. The cytoprotective effects are mainly mediated by upregulated intracellular antioxidant enzyme activity.

In the present study, it was revealed that QSWE prevented alloxan-induced cell death, as assessed by MTT assays. The results showed that QSWE alone was not significantly cytotoxic to cells at the tested concentrations. Treatment with QSWE exhibited significant protective effects which may be due to the free radical scavenging activity of QSWE.

To evaluate the role of the free radicals in the protective activity of QSWE, the effect on alloxan-induced ROS generation was analyzed using $\mathrm{H}_{2}$ DCF-DA assays. Treatment with alloxan alone significantly increased the intracellular ROS generation. Following treatment with QSWE, ROS generation was observed to decline in a concentration-dependent manner. This decrease in alloxan-induced ROS may account for the observed cytoprotective effect.

Lipid peroxidation is the most extensively investigated process induced by free radicals. ROS participate in the toxic actions that lead to the apoptosis of insulin-producing cells. In the present study, increased lipid peroxidation levels were observed in alloxan-treated HIT-T15 cells. However, treatment with QSWE resulted in a decrease in lipid peroxidation, indicating that oxidative stress-related damage was lower in the QSWE-treated cells. The capacity of QSWE to reduce lipid peroxidation may be due to its function as a preventive antioxidant for scavenging initiating radicals.

Overproduced free radicals are scavenged by endogenous antioxidant enzymes, including SOD, CAT and GSH-px. In cells, SOD catalyzes the conversion of superoxide $\left(\mathrm{O}_{2}^{-}\right)$to hydrogen peroxide $\left(\mathrm{H}_{2} \mathrm{O}_{2}\right)$ and $\mathrm{H}_{2} \mathrm{O}_{2}$ is further reduced $\mathrm{H}_{2} \mathrm{O}$ by the activity of CAT or GSH-px. Pancreatic $\beta$ cells have been reported to contain low levels of endogenous antioxidant enzymes, in particular GSH-px and CAT (16). In the present study, alloxan significantly decreased the activity of GSH-px and CAT in HIT-T15 cells. However, QSWE treatment increased the activity of these antioxidant enzymes in the 
alloxan-treated HIT-T15 cells, indicating that QSWE was able to reduce alloxan-induced oxidative stress. Certain studies have reported that the overexpression of $\mathrm{Cu} / \mathrm{Zn}-\mathrm{SOD}$ showed a protective effect against nitric oxide-induced cytotoxicity in human islets and INS-1 insulin-secreting cells (17) and alloxanand streptozotocin-induced diabetes $(18,19)$. CAT also showed a protective effect against $\mathrm{H}_{2} \mathrm{O}_{2}$ - and streptozotocin-induced oxidative stress in vivo (20). In addition, the combined overexpression of CAT and GSH-px also revealed a protective effect against ROS-induced oxidative stress by increasing the activity of $\mathrm{Cu} / \mathrm{Zn}$ SOD or MnSOD (21-23).

In conclusion, in the present study, QSWE demonstrated protective activity against alloxan-induced cell death in HIT-T15 hamster insulin-secreting cells. QSWE was able to effectively scavenge alloxan-induced intracellular ROS and prevent pancreatic $\beta$ cell death by increasing the activity of the intracellular antioxidant enzymes SOD, CAT and GSH-Px. Furthermore, QSWE also promoted insulin secretion in the alloxan-treated HIT-T15 cells.

\section{References}

1. Evans JL, Goldfine ID, Maddux BA and Grodsky GM: Are oxidative stress-activated signaling pathways mediators of insulin resistance and $\beta$-cell dysfunction? Diabetes 52: 1-8, 2003.

2. Rahimi R, Nikfar S, Larijani B and Abdollahi M: A review on the role of antioxidants in the management of diabetes and its complications. Biomed Pharmacother 59: 365-373, 2005.

3. Robertson RP and Harmon JS: Diabetes, glucose toxicity, and oxidative stress: a case of double jeopardy for the pancreatic islet $\beta$ cell. Free Radic Biol Med 41: 177-184, 2006.

4. Bell DS: Do sulfonylurea drugs increase the risk of cardiac events? CMAJ 174: 185-186, 2006.

5. Home PD, Pocock SJ, Beck-Nielsen H, Gomis R, Hanefeld M, Jones NP, Komajda M and McMurray JJ; RECORD Study Group: Rosiglitazone evaluated for cardiovascular outcomes - an interim analysis. N Engl J Med 357: 28-38, 2007.

6. Bailey CJ and Day C: Traditional plant medicines as treatments for diabetes. Diabetes Care 12: 553-564, 1989.

7. Redwane A, Lazrek H, Bouallam S, Markouk M, Amarouch H and Jana M: Larvicidal activity of extracts from Quercus lusitania var. infectoria galls (Oliv.). J Ethnopharmacol 79: 261-263, 2002.

8. Goun EA, Petrichenko VM, Solodnikov SU, Suhinina TV, Kline MA, Cunningham G, Nguyen C and Miles H: Anticancer and antithrombin activity of Russian plants. J Ethnopharmacol 81: 337-342, 2002

9. Kim J, Kim H, Kim S, Lee K, Ham I and Whang WK: Antioxidative compounds from Quercus salicina Blume stem. Arch Pharm Res 31: 274-278, 2008.
10. Fraga CG, Leibovitz BE and Tappel AL: Lipid peroxidation measured as thiobarbituric acid-reactive substances in tissue slices: characterization and comparison with homogenates and microsomes. Free Radic Biol Med 4: 155-161, 1988.

11. Nelson D and Kiesow L: Enthalpy of decomposition of hydrogen peroxide by catalase at 25 degrees $\mathrm{C}$ (with molar extinction coefficients of $\mathrm{H}_{2} \mathrm{O}_{2}$ solutions in the UV). Anal Biochem 49: 474-478, 1972.

12. Marklund S and Marklund G: Involvement of the superoxide anion radical in the autoxidation of pyrogallol and a convenient assay for superoxide dismutase. Eur J Biochem 47: 469-474, 1974.

13. Hafeman DG, Sunde RA and Hoekstra WG: Effect of dietary selenium on erythrocyte and liver glutathione peroxidase in the rat. J Nutr 104: 580-587, 1974.

14. Robertson RP, Harmon J, Tran PO, Tanaka Y and Takahashi H: Glucose toxicity in $\beta$-cells: type 2 diabetes, good radicals gone bad, and the glutathione connection. Diabetes 52: 581-587, 2003.

15. Cheng Q, Law PK, de Gasparo M and Leung PS: Combination of the dipeptidyl peptidase IV inhibitor LAF237 [(S)-1-[(3-hydroxy-1-adamantyl)ammo] acetyl-2-cyanopyrrolidine] with the angiotensin II type 1 receptor antagonist valsartan [N-(1-oxopentyl)-N-[[2'-(1H-tetrazol-5-yl)-[1, 1'-biphenyl]-4-yl] methyl]-L-valine] enhances pancreatic islet morphology and function in a mouse model of type 2 diabetes. J Pharmacol Exp Ther 327: 683-691, 2008.

16. Zhang H, Öllinger $\mathrm{K}$ and Brunk U: Insulinoma cells in culture show pronounced sensitivity to alloxan-induced oxidative stress. Diabetologia 38: 635-641, 1995.

17. Moriscot C,Pattou F,Kerr-Conte J,Richard MJ,Lemarchand P and Benhamou PY: Contribution of adenoviral-mediated superoxide dismutase gene transfer to the reduction in nitric oxide-induced cytotoxicity on human islets and INS-1 insulin-secreting cells. Diabetologia 43: 625-631, 2000.

18. Kubisch HM, Wang J, Bray TM and Phillips JP: Targeted overexpression of $\mathrm{Cu} / \mathrm{Zn}$ superoxide dismutase protects pancreatic $\beta$-cells against oxidative stress. Diabetes 46: 1563-1566, 1997.

19. Kubisch HM, Wang J, Luche R, Carlson E, Bray TM, Epstein CJ and Phillips JP: Transgenic copper/zinc superoxide dismutase modulates susceptibility to type I diabetes. Proc Natl Acad Sci USA 91: 9956-9959, 1994.

20. Xu B, Moritz JT and Epstein PN: Overexpression of catalase provides partial protection to transgenic mouse beta cells. Free Radic Biol Med 27: 830-837, 1999.

21. Lortz S and Tiedge M: Sequential inactivation of reactive oxygen species by combined overexpression of SOD isoforms and catalase in insulin-producing cells. Free Radic Biol Med 34: 683-688, 2003.

22. Lepore DA, Shinkel TA, Fisicaro N, Mysore TB, Johnson LE, d'Apice AJ and Cowan PJ: Enhanced expression of glutathione peroxidase protects islet $\beta$ cells from hypoxia-reoxygenation. Xenotransplantation 11: 53-59, 2004.

23. Mysore TB, Shinkel TA, Collins J, Salvaris EJ, Fisicaro N, Murray-Segal LJ, Johnson LE, Lepore DA, Walters SN, Stokes R, Chandra AP, O'Connell PJ, d'Apice AJ and Cowan PJ: Overexpression of glutathione peroxidase with two isoforms of superoxide dismutase protects mouse islets from oxidative injury and improves islet graft function. Diabetes 54: 2109-2116, 2005. 